\title{
Toruński jubileusz 70-lecia Profesor Haliny Robótki i księga jubileuszowa Jej poświęcona
}

W ubiegłym roku prof. dr hab. Halina Robótka, założycielka i długoletnia kierowniczka Zakładu Zarządzania Dokumentacją i Informacji Archiwalnej w Instytucie Historii i Archiwistyki Uniwersytetu Mikołaja Kopernika w Toruniu, obchodziła 70. urodziny, kończąc jednocześnie pracę w uniwersytecie, któremu poświęciła 46 lat życia. Z tej okazji grono jej najbliższych współpracowników, przyjaciół, koleżanek i kolegów z Torunia oraz z innych ośrodków akademickich zebrało się na jej zaproszenie, aby wspólnie uczcić ten jubileusz. Spotkanie odbyło się 21 listopada 2016 r. w toruńskiej restauracji Karczma „Spichrz” na Starym Mieście, gdzie przy zastawionym stole i dobrym winie świętowano ten ważny dla Jubilatki i jej Zakładu moment. Wtedy też nadszedł czas na wspomnienia Jubilatki z okresu jej pracy w Archiwum Państwowym w Bydgoszczy oraz w UMK, a także na wyrażenie przez obecnych uznania dla jej dorobku naukowego, dydaktycznego i organizacyjnego oraz ciepłych słów za przyjaźń, którą okazywała wielu koleżankom i kolegom.

W swojej pracy dydaktycznej i organizacyjnej odnosiła liczne sukcesy, wychowała pokaźne grono magistrów, licencjatów, dyplomantów oraz pięciu doktorów, zorganizowała wiele konferencji poświęconych problematyce zarządzania dokumentacją. Najważniejszym obszarem aktywności prof. H. Robótki były jednak badania naukowe z zakresu archiwistyki i dziejów kancelarii. Emerytura zazwyczaj nie przerywa aktywności naukowej, a w niektórych przypadkach nawet ją intensyfikuje, i właśnie tego życzono Jubilatce, jak również dobrego zdrowia i ludzkiej życzliwości.

H. Robótka urodziła się w Szubinie, w którym ukończyła też szkołę podstawową. Naukę kontynuowała w I Liceum Ogólnokształcącym w Bydgoszczy, w którym w roku 1964 uzyskała maturę. Podstawy teoretyczne archiwistyki i wiedzę praktyczną z jej zakresu zapewniły jej studia historyczno-archiwalne w UMK w latach 1964-1969, a szczególnie uczestnictwo w seminarium wybitnego archiwisty i historyka prof. Andrzeja Tomczaka. Pod jego kierunkiem napisała pracę magisterską Źródła kartograficzne do dziejów Torunia w aktach gruntowych Urzędu Budowlanego w Toruniu (1793-1920). Po ukończeniu studiów dwa lata pracowała w Archiwum Państwowym w Bydgoszczy, w którym zajmowała się 
opracowywaniem akt najnowszych oraz nadzorem nad narastającym zasobem, a także udostępnianiem dokumentacji.

W roku 1971 zyskała szansę podjęcia pracy naukowo-dydaktycznej w Zakładzie Archiwistyki kierowanym przez prof. A. Tomczaka, co miało przełomowe znaczenie w jej życiu. W roku 1980 obroniła pracę doktorską Mapa jako obiekt archiwalny, której promotorem był prof. A. Tomczak. Habilitowała się w swojej macierzystej uczelni w roku 1993 na podstawie rozprawy Kancelaria urzędów administracji państwowej w II Rzeczypospolitej. W roku 2000 uzyskała stanowisko profesora UMK, a w roku 2005 Prezydent RP nadał jej tytuł profesora nauk humanistycznych. Od roku 2001 kierowała Pracownią Komputeryzacji Archiwów, która w roku 2006 została przekształcona w istniejący do dzisiaj Zakład Zarządzania Dokumentacją i Informacji Archiwalnej.

Prof. H. Robótka posiada imponujący dorobek w zakresie opracowywania podręczników archiwalnych. Pod tym względem jest niekwestionowaną liderką w polskim środowisku uniwersyteckim. Już w latach 80 . przygotowała skrypt dotyczący dokumentacji kartograficznej Rozwój form kancelaryjnych i współczesne rodzaje dokumentów archiwalnych. Dokumentacja geodezyjno-kartograficzna, Toruń 1985 oraz opracowanie dokumentacji mechanicznej Metodyka archiwalna. Opracowanie dokumentacji geodezyjno-kartograficznej, technicznej, audiowizualnej (fotografii, filmów i mikrofilmów, nagrań), Toruń 1988.

Jubilatka była współautorką jedynego podręcznika z zakresu całej dyscypliny Archiwistyka (razem z profesorami B. Ryszewskim i A. Tomczakiem), opublikowanego w roku 1989 w Warszawie przez Państwowe Wydawnictwo Naukowe. W ostatnim okresie samodzielnie przygotowała cenione i wykorzystywane na wyższych uczelniach podręczniki Wprowadzenie do archiwistyki, Toruń 2002 i 2003 oraz Opracowanie i opis archiwaliów. Podręcznik akademicki, Toruń 2010. Bardzo przydatny dla archiwistów oraz pracowników administracji okazał się również podręcznik autorstwa Jubilatki z zakresu pracy kancelaryjnej Wspótczesna biurowość. Zagadnienia ogólne, Toruń 2010.

Godne uwagi są też prace naukowe Jubilatki, wśród których najważniejsza jest jej rozprawa habilitacyjna. W przejrzysty sposób ukazała w niej istotę i zakres reformy kancelaryjnej przeprowadzonej w okresie międzywojennym. Dzięki temu bardzo dobrze sprawdza się ona w dydaktyce uniwersyteckiej - o wiele bardziej niż inne monografie i artykuły poświęcone dziejom kancelarii okresu II Rzeczypospolitej oraz okresu powojennego. Ważne miejsce w dorobku naukowym Jubilatki zajmują również prace poświęcone komputeryzacji archiwów, a szczególnie 
dotyczące opisu dokumentacji geodezyjno-kartograficznej, jej struktury, a także problemowi zespołowości w archiwach.

Godnym zwieńczeniem jubileuszu prof. H. Robótki było wręczenie jej okazałej księgi jubileuszowej Zarządzanie dokumentacja, archiwistyka i... koty, którą wydała Naczelna Dyrekcja Archiwów Państwowych w Warszawie za zgodą jej dyrektora prof. Władysława Stępniaka. Redagowali ją prof. dr hab. Wanda K. Roman, następczyni prof. H. Robótki na stanowisku kierownika Zakładu Zarządzania Dokumentacją i Informacji Archiwalnej, oraz uczniowie Jubilatki, doktorzy habilitowani Robert Degen i Marlena Jabłońska. Ten wartościowy tom ukazał się tuż przed opisywanym uroczystym spotkaniem i stanowił wyraz szczególnego uznania dla Jubilatki ze strony autorów tekstów zamieszczonych w Księdze oraz osób, które wpisały się na listę gratulacyjną, reprezentujących różne środowiska naukowe i archiwalne.

Księgę otwierają wstęp, autorstwa jej redaktorów, tabula gratulatoria, biografia Jubilatki, również napisana przez nich (s. 9-17), wykazy prac licencjackich i magisterskich powstałych pod jej kierunkiem, sporządzone przez Bożenę Kierzkowską (s. 18-31), a także spis rozpraw doktorskich, które promowała Jubilatka (s. 32). Po nich zamieszczono artykuły 25 autorów pochodzących z Torunia, Warszawy, Poznania, Lublina, Bydgoszczy, Gdyni, Opola i Piotrkowa Trybunalskiego. Podzielono je na cztery grupy rzeczowe: zarządzanie dokumentacją; archiwistyka, archiwa, archiwiści; edukacja w świecie archiwów; źródła, badania. Problematyką tą zajmowała się Jubilatka w sposób twórczy w trakcie swojej działalności naukowej i dydaktycznej.

Autorzy tekstów skupili się przeważnie na problematyce dziejów kancelarii oraz archiwoznawstwa, co świadczy o szczególnym ich uznaniu dla głównych kierunków zainteresowań badawczych toruńskiej Jubilatki. Zagadnień związanych z praktyką kancelaryjną dotyczyły teksty Doroty Drzewieckiej (Kraków), O dwóch galicyjskich podręcznikach z poczatku XX w. przeznaczonych dla sądowego personelu biurowego (s. 33-43), Roberta Degena (Toruń), Jeszcze o instrukcji kancelaryjnej (s. 45-55), Marcina Hlebionka (Toruń), Instrukcje w sprawie używania pieczęci. Przykład Zakładów Telkom-Telfa w Bydgoszczy (s. 65-82) oraz Pauliny Bunkowskiej (Toruń), Praktyka postępowania $z$ dokumentacja projektów wspólfinasowanych ze środków Unii Europejskiej i innych źródeł zewnętrznych na Uniwersytecie Mikołaja Kopernika $w$ Toruniu (s. 83-92).

Równie bogata i zróżnicowana treściowo okazała się część archiwoznawcza Księgi. Znalazły się w niej artykuły Wiesławy Kwiatkowskiej (Toruń), Wkład ogólnopolskich konferencji metodycznych $w$ rozwój metodyki kształtowania zasobu archiwalnego (s. 107-121), Marleny Jabłońskiej (Toruń), Archiwum jako marka. Korzyści 
z bycia rozpoznawalnym (s. 123-132), Krzysztofa Syty (Toruń), Białostockie archiwum Branickich w II połowie XVIII w. w świetle listów Piotra Piramowicza do Izabeli Branickiej z lat 1773-1785 (s. 133-144), Wandy Krystyny Roman (Toruń), Stużba archiwalna 2 Korpusu Polskiego (s. 145-153), Tomasza Foltyna (Opole), Utworzenie i poczatki działalności Powiatowego Archiwum Państwowego w Brzegu (s. 155-163).

Problematykę archiwalno-metodyczną reprezentują artykuły Agnieszki Woźniak-Hlebionek (Bydgoszcz), Problemy opracowania zespołu „Komisja Generalna w Bydgoszczy". Od urzędnika pruskiego do polskiego archiwisty (s. 177-191), Jolanty Musiał (Gdynia), $Z$ magazynu archiwalnego do rąk użytkownika. $Z$ doświadczeń trójmiejskich archiwistów nad opracowaniem Akt Wydawnictwa Morskiego (s. 193203), Tomasza Maruszaka (Piotrków Trybunalski), AdolfErazm Mysłowski - archiwista niezłomny (s. 205-216) oraz Władysława Stępniaka (Warszawa), Udział Polski w pracach UNESCO dotyczacych zalecenia w sprawie ochrony i dostępności dziedzictwa dokumentacyjnego, w tym cyfrowego (s. 227-233).

Dydaktyka uniwersytecka zajmowała wiele miejsca w działalności Jubilatki i na tym polu może poszczycić się znaczącymi osiągnięciami. Z tego względu w Księdze nie mogło zabraknąć tekstów poświęconych tym problemom, i to zarówno w przestrzeni uniwersyteckiej, jak i szkolnej. Reprezentowały je artykuły Ireny Mamczak-Gadkowskiej (Poznań), Doświadczenia poznańsko-toruńskiej wspólpracy $w$ procesie uniwersyteckiego ksztatcenia i doskonalenia zawodowego archiwistów (s. 237-248), Hanny Krajewskiej (Warszawa), Pikniki Archiwalne - pomysł na promocjęarchiwów (s. 255-260) oraz Macieja J. Jasińskiego (Warszawa), Archiwistyka dla najmłodszych (s. 261-267).

Całość Księgi zamykają trzy opracowania źródłoznawcze i historyczne autorów reprezentujących macierzystą uczelnię Jubilatki. Są to artykuły Andrzeja Radzimińskiego i Janusza Tandeckiego, Źródła do dziejów Zakonu Krzyżackiego w wybranych polskich archiwach państwowych i kościelnych (Warszawa, Kraków, Gdańsk, Elbląg, Toruń, Olsztyn) (s. 271-282), Adama Kucharskiego, Źródła do dziejów podróży zagranicznych polskiej magnaterii w epoce nowożytnej (XVI-XVIII w.) w wybranych archiwach rodzinnych przechowywanych w Archiwum Głównym Akt Dawnych $w$ Warszawie. Materialy edytorskie, stan badań (s. 283-292) oraz Zofii Waszkiewicz, $Z$ badań nad dziejami protestantyzmu w Polsce i na emigracji (s. 293-302).

Oryginalna, choć intrygująca, końcowa część tytułu Ksiegi przestała być zagadką dzięki esejowi uczennicy Jubilatki - Katarzyny Pepłowskiej (Kocie zakątki, s. 305311), poświęconemu stosunkowi ludzi do kotów w różnych kulturach. Autorka, pisząc go, dała wyraz wielkiej sympatii Jubilatki do tych zwierząt. Kończąc swój tekst, przypomniała opinię Alberta Schweitzera, znanego duchownego luterańskiego, 
teologa, muzykologa i lekarza, który za założenie szpitala w Lambaréné w Gabonie otrzymał w roku 1952 Pokojową Nagrodę Nobla. Otóż, powiedział on, że ucieczkę od prozy życia umożliwiają tylko muzyka i koty.

Przedstawiciele lubelskiego środowiska historycznego, reprezentujący UMCS i Archiwum Państwowe, zamieścili w Księdze pięć tekstów, co spowodowało, że pod względem pochodzenia geograficznego jej współautorów lubelski ośrodek znalazł się na drugim miejscu po Toruniu. Piotr Romanowski, związany wcześniej z Archiwum, przedstawił jeden $\mathrm{z}$ istotnych problemów kancelaryjnych przedwojennego MSZ (Obieg pism w centrali Ministerstwa Spraw Zagranicznych w latach 1918-1939. Zarys problematyki, s. 57-63). Marek Konstankiewicz z UMCS zaprezentowal istotny aspekt problematyki prawnej w działalności archiwów (Status archiwum bieżącego we współczesnym polskim prawie archiwalnym, s. 93-104), a Piotr Dymmel, łączący środowisko archiwalne i uniwersyteckie, dokonał charakterystyki dorobku edytorskiego kierowanej przez siebie placówki (Udział Archiwum Państwowego w pracach nad wydawaniem źródeł historycznych, s. 165-176). Natomiast Anna Łosowska z UMCS opisała doświadczenia w zakresie praktycznego podnoszenia kwalifikacji zawodowych studentów archiwistyki (Studenckie wolontariackie staże archiwalne. $Z$ doświadczeń Archiwum Uniwersytetu Marii Curie-Skłodowskiej, s. 249-244). Nurt badań biografii wybitnych archiwistów reprezentował artykuł napisany przez autora tego sprawozdania, także z UMCS (Wspomnienia legionowe Kazimierza Konarskiego, s. 217-226).

Prof. Halina Robótka, dziękując redaktorom Księgi i autorom zamieszczonych w niej artykułów, w żartobliwym tonie zwróciła uwagę na altruistyczny aspekt ich pracy. Stwierdziła, że być może nie będą mogli otrzymać za swoje teksty punktów, tak bardzo pożądanych przy ocenie ich dokonań naukowych. W jej przekonaniu mogła zdecydować o tym niemająca nic wspólnego z naukową powagą frywolna końcówka tytułu Księgi. Nie wiem, czy tak się stanie, ale jestem przekonany, że zdecydowana większość autorów, przygotowując swoje artykuły do tego jubileuszowego tomu, zupełnie nie myślała o uzyskaniu za nie gratyfikacji punktowej. Bardziej zależało im na wyrażeniu szacunku dla osoby Jubilatki oraz uznania dla jej osiągnięć we wszystkich sferach aktywności cechujących wybitnych profesorów. Toruńskie środowisko naukowe może być natomiast dumne z dokonań Jubilatki, ponieważ to na jego rzecz konsekwentnie i nadzwyczaj owocnie pracowała ona przez cały okres swojej długiej pracy uniwersyteckiej. 